\title{
The Effect of COVID-19 Pandemic on Consumer Online Purchasing Behavior
}

\author{
NOUR MARWAN QTAISHAT \\ Al Balqa ’Applied University \\ PO.Box.19117 \\ Faculty Salt College, Salt, JORDAN
}

\begin{abstract}
This study aimed to explore the impacts of COVID 19 pandemic on the consumer online purchasing behaviors in Jordan. A descriptive analytical approach was adopted. The population involves all the online consumers in Jordan who shopped online during the pandemic. The researcher passed the questionnaire forms to 200 students by email who were selected from three Jordanian universities that are located in Amman. Those students were selected randomly. All the forms were filled and retrieved. All the retrieved forms were analyzed statistically. The response rate is $100 \%$. The questionnaire was developed by the researcher based on the literature that was reviewed. SPSS software was used. Means and standard deviations are calculated. The researcher concluded the COVID 19 pandemic has a moderate impact on consumer online purchasing behaviors in Jordan. That was concluded from the perspective of the students who are enrolled at Jordanian universities. The researcher found that there are differences between the respondents' views which are attributed to gender for the favor of females. She recommends taking the recent purchasing trends into consideration when setting marketing plans by plan developers.
\end{abstract}

Keywords: COVID-19 pandemic, consumer, purchasing behavior, Jordanian universities.

Received: November 19, 2021. Revised: April 30, 2021. Accepted: May 9, 2021. Published: May 19, 2021.

\section{Introduction}

Possessing knowledge about customers and their demands contributes to advertising products in an effective manner. However, the owners of many companies are unable to advertise their products in an efficient manner. In this context, such owners must provide much attention to electronic advertisement during the COVID 19 pandemic. That's because customers during the COVID 19 pandemic purchase products through websites instead of purchasing products face to face.

The COVID-19 pandemic affected the consumption behavior of people. That is attributed to having a decrease in income. It is attributed to the enforcement of measures to prevent the COVID 19 virus from spreading. It's attributed to having fears and concerns.
It's attributed to the changes that occurred to people's daily routine and life styles. It's attributed to the social distancing measures that were taken by people. Such measures reduced the interpersonal communication between people.

The COVID-19 pandemic affected the consumer behavior. It negatively affected the national economy of all countries and the financial status of millions of people. It caused a global economic recession. Due to experiencing such a recession, the consumer behaviors have changed worldwide. That negatively almost all sectors [3].

E-marketing has become very significant due to the COVID 19 pandemic. For instance, all companies started using electronic means to advertise their products and services during this pandemic. That's because such means are characterized with low cost. 
It is because such means allow companies to contract numerous customers.

Based on report No. [13], the volume of e-commerce sales IN 2018 is represented in 25.6 trillion USD worldwide. Based on the latter number, there is an increase of $8 \%$ in comparison to the prior year. The latter report suggests that around 1.45 billion people around the world purchased something online during the year 2018. It suggests that around 1 person from each 4 people whose age is 15 years or older world purchased something online during the year 2018 [13].

E-commerce has become essential during the last couple of years. Due to the COVID 19 pandemic, the role of e-commerce became prominent. It contributes to reducing the severity of the negative impacts of this pandemic. Such negative impacts are attributed to the restrictions imposed on movement during this pandemic. For instance, this pandemic negatively affected the consumer purchasing behavior. In addition, due to the decisions made by the government, the use of e-commerce channels during this pandemic increased significantly [14].

Due to the increasing use of internet services, online shopping means have become the main shopping means during the COVID 19 pandemic. That is because online shopping means allow consumers to order services and goods online and use online payment methods. It is because online shopping means allow consumers to avoid fact to face contact. Thus, such means allow consumers to avoid getting infected with this virus. Online shopping means have become the main shopping means during the COVID 19 pandemic due to the restrictions imposed over movement during this pandemic [1].

The emergence of online shopping led to having major changes to the marketing strategies employed by sellers during recent decades. Such changes have been increasing, because the number of online consumers has been increasing worldwide [2].

The pandemic is a global crisis that began during the year 2020. In fact, it affected people in various aspects. For instance, it changed people's view towards education due to having changes in the way of delivering education. For instance, during this crisis, people received education through using online learning platforms [18].

Due to suffering from this crisis, supermarkets have been suffering from panic. This panic affected their purchasing behavior. For instance, due to this health crisis, the shelves in millions of stores became out of stocks. The food consumption of consumers significantly increased. In addition, the online sales volume has significantly increased. Marketers, the owners of supermarkets, producers, and businessmen adapted their plans, decisions and measures in accordance with the changes that occurred to consumer behavior [4].

Due to the COVID 19 pandemic, the shopping preferences of consumers have significantly changed. The latter pandemic made consumer shift from carrying out face to face shopping into carrying out online shopping.

The pandemic changed many aspects in life. For instance, it changed the consumer behaviors. For instance, it made consumers rush to stores to purchase a great amount of groceries due to the major panic experienced by consumers. However, later on, the government promoted awareness among consumers about the fact that groceries shall not be missing from markets. It promoted awareness about the role of the government in managing the Coronavirus crisis. Such awareness contributed to rationalizing the consumption of groceries by consumers [15].

Many changes occurred to the purchasing behavior of the public due to his pandemic. For instance, many consumers started purchasing products in a manner that exceed their needs. That is done in the aim of ensuring that their families' needs are met. It is attributed to psychological reasons derived from this pandemic. For instance, many people have concerns about the effectiveness of the vaccine of COVID 19. That led to the prevalence of stress and anxiety [16]. Sharma \& Jhamb [5] suggest that this pandemic 
changed the types of products that are ordered the most online by consumers. For instance, the extent of ordering personal care products and medical kits online significantly increased due to the pandemic. The extent of ordering fashion products online during this pandemic has decreased.

There are many factors that affect the consumer purchasing behaviors, including the online purchasing behaviors. Such factors include: the COVID 19 pandemic. This pandemic is the most significant factor among those factors.

\section{Statement of the Problem}

This pandemic affects the consumer behavior. It affects the economic and financial decisions made by people. That is because this pandemic led to the spread of fear, panic, and pessimism about the future among people. It is because this pandemic affected the financial status of millions of consumers worldwide due to the decline of their income and the rise of unemployment rate. It should be noted that the decline of income affected the consumption decisions and patterns of consumers. Therefore, the study's problem lies in this question:

(What are the impacts of COVID 19 pandemic on the consumer online purchasing behaviors in Jordan?). In other words, through this study, the researcher explored the changes that occurred to the consumption patterns of consumers in Jordan during the pandemic. Through this study, he explored the attitudes of consumers in Jordan towards online shopping during this pandemic.

\section{Objectives and Questions}

This study investigated the impacts of this pandemic on consumer online purchasing behaviors. It investigated whether there is any significant difference between the attitudes of respondents which can be attributed to (gender, university, or faculty type).
The data was collected from students enrolled at Jordanian universities.

The researcher aimed to answer those questions:

Q.1: What are the impacts of COVID 19 pandemic on the consumer online purchasing behaviors in Jordan?

Q.2. Is there any significant difference between the respondents' attitudes which can be attributed to (gender, university, or faculty type)?

\section{The Study's Significance}

This study is deemed significant because it sheds a light on the impacts of this pandemic on the consumer online purchasing behaviors. It is deemed significant because it sheds a light on the changes that occurred to the consumer purchasing behaviors in Jordan. Such changes are attributed to the measures and restrictions enforced to prevent this virus from spreading. They are attributed to the decline of income.

This study is deemed significant because through reaching intended results, the decision makers in business organizations shall be more capable of making effective decisions for meeting the demands and needs of consumers during the pandemic. In addition, reaching the intended results shall enable policy makers in public agencies to make effective plans and policies for meeting the demands and needs of consumers during the pandemic. It shall enable policy makers in public agencies to make effective plans and policies for improving the national economy.

\section{Definitions}

Covid-19 pandemic: It refers to the spread of a respiratory infectious virus. It is a one of the Coronavirus strain. It emerged for the first time in 2019 in a Chinese city called (Wuhan). It has spread worldwide [13]. 
Consumer purchasing Behavior: It refers to the behaviours that are carried out by consumers when searching for products and using them [12].

\section{Limits}

This study was conducted in the Jordanian universities that are located in Amman. It was conducted during the following period: (Nov. $2020-$ Jan.2021).

\section{Review of literature}

Bayad [1] investigated the effects of this pandemic on the purchasing behaviors of consumers in terms of electronic durable goods in Iraq. He reviewed the relevant literature to collect data. He collected secondary data from the Samsung Company. He concluded that this pandemic made Iraqi consumers embrace the use of technologies and adapt their lifestyles with the enforced restrictions and current circumstances.

Gustav \& Alexandra [4] investigated the effects of this pandemic on the consumer purchasing behavior. They investigated such effects in terms of purchasing meat, and fruits and vegetables. They adopted a quantitative approach. Questionnaire forms were passed to consumers in Austria and Sweden. 169 forms were retrieved and analyzed. The result suggests that the consumer purchasing behavior - in terms of purchasing meat, and fruits and vegetablesis affected by this pandemic

Sharma \& Jhamb [5] investigated the impact of this pandemic on the purchasing behaviors of consumers. They targeted various perspectives and issues. They shed a light on online marketing-related issues. They add that the sale volume shall affect the global community. They investigated the effect of the pandemic on the purchasing behaviors of consumer in terms of purchasing toilet tissue rolls, baby gear, and pet food. They found that many companies used social media and website to sell their services and products. $46 \%$ of the respondents suggest that social media is essential for sharing information and making purchasing decisions. The researchers found that this pandemic caused a major financial loss. They found that people shall shift to face to face shopping once this pandemic ends.

Pham et al. [6] investigated the way in which the behaviors of online shoppers changed due to this pandemic. Data was gathered from 427 online shoppers. It was collected during this pandemic. The gathered data was analyzed. The latter researchers found that this pandemic has a moderate effect on the consumer's awareness of utilities. Thus, consumers seek carrying out online shopping rather than face to face shopping. The researchers found that the marketing policies don't significantly affect the online shopping behavior. They found that having awareness about this pandemic doesn't affect the online shopping behavior. The results reached by the latter researchers contribute to achieving a deeper understanding for consumer behaviors.

Vijai \& Nivetha [8] investigated the consumer purchasing behavior during this pandemic in Chennai. Regarding the primary data, it was gathered by the latter researcher through the use of a structured questionnaire. It was obtained from 256 respondents. Most of the respondents are males (52.3\%). The researcher found that the most respondents work in the private sector $(58.6 \%)$. The collected data was analyzed through SPSS. Through carrying out the chisquare test, the relationship between several variables was explored. The latter researchers found that the consumer purchasing behaviors have changed significantly due to the COVID 19 pandemic. They found that consumers spend more money on medical and hygiene products during the latter pandemic. They found that the latter pandemic affects the shopping behavior, brand preference, and purchasing decision.

Debnath [9] investigated the impact of this pandemic on the purchasing behaviors of consumers in the retail sector. The convenience sampling method was 
employed. The latter researcher collected data fromdetermining the effect of several online purchase 152 individuals in Kolkata. Data was collected fromdeterminants on the consumer satisfaction in Serbia. This those individuals through using an onlinemodel consists from twenty six (26) elements. Those questionnaire. Several statistical methods were used.elements are categorized into 7 variables. Those variables For instance, the multiple regression analysis wasare: information availability, security, quality, pricing, conducted. It was found that the major rise in pricestime, shipping, and customer satisfaction. Input model and the delay of the delivery of online servicesparameters were collected through the use of surveys. affected the consumer purchasing behavior. The The validity of the model was checked by the researchers purchasing behavior of the male respondents whosethrough performing the Confirmatory Factor Analysis income is within the range of 0-30,0000 are affectedand the Partial Least Squares. Through analyzing data, much by this pandemic. The ones whose ages rangethe researchers found that information availability, between 25 - 35 years are influenced by thissecurity, quality, pricing, time, and shipping affect pandemic. Therefore, there is a relationship betweenconsumer satisfaction. income from one hand and the purchasing behavior during the pandemic from another hand. In addition, there is a relationship between age from one hand and the purchasing behavior during the pandemic from another hand.

Butu et al [10] investigated the influence of this pandemic on the purchasing behaviors of consumers in terms of purchasing fresh vegetables from local producers in Suceava, Romania during the quarantine. They collected data from 257 consumers through the use of an online questionnaire. Socio-demographic data was collected about the sampled consumers. The latter researchers found that the latter pandemic significantly affected the consumer purchasing behavior in terms of purchasing fresh vegetables.

Koch et al. [11] examined the online shopping motives of generation $\mathrm{Y}$ and $\mathrm{Z}$ during the COVID-19 lockdown. They targeted April, 2020. They collected data from 451 German consumers through using a surveys. They found that normative determinants (e.g. media reports about the economic status) affect the purchasing intentions of consumers. They found that hedonic motivation is a better predictor for the purchasing intention than utilitarian motives. They found that women show higher hedonic motivation levels than males. The same applies to the ones who carry out social distancing measures.

Vasic et al. [7] investigated the relationship between customer satisfaction from one hand and several variables from another hand. They developed a model for

\section{Methodology}

\section{Approach:}

The researcher adopted a descriptive analytical approach. The latter approach is usually adopted in the aim of providing readers with a sensory description for phenomena, things and items. It is also adopted in the aim of identifying whether the identified sensory attributes are accepted or not. It is also adopted in the aim of understanding and investigating certain variables [17].

\section{Sources of Data}

Primary and secondary sources of data were utilized for gathering the required data. For instance, the primary source involves the questionnaire that's designed for gathering data about respondents' views. The secondary sources include: theses, journal articles and books.

\section{Population:}

The population involves all the online consumers in Jordan who shopped online during the pandemic.

\section{Sample:}

The researcher passed the questionnaire forms to 200 students by email who were selected from three Jordanian universities that are located in Amman. Those students were selected randomly. All the forms were filled and retrieved. All the retrieved forms were analyzed statistically. The response rate is $100 \%$. The questionnaire was developed by the 
researcher based on the literature that was reviewed. Table 1 presents the distribution of the sampled students in accordance with gender, university and faculty type.

Table 1. Data about respondents in terms of (university, gender, and faculty type).

\begin{tabular}{|l|l|l|l|}
\hline Variable & Category & Frequency & Percent \\
\hline \multirow{5}{*}{ University } & $\begin{array}{l}\text { University of } \\
\text { Jordan }\end{array}$ & 88 & 44.0 \\
\cline { 2 - 4 } & $\begin{array}{l}\text { Princess } \\
\text { Sumaya } \\
\text { University } \\
\text { For } \\
\text { Technology }\end{array}$ & 65 & 32.5 \\
\cline { 2 - 4 } & $\begin{array}{l}\text { Applied } \\
\text { Science } \\
\text { Private }\end{array}$ & 47 & 23.5 \\
\hline University & Total & 200 & 100.0 \\
\cline { 2 - 4 } Gender & Male & 119 & 59.5 \\
\cline { 2 - 4 } & Female & 81 & 40.5 \\
\cline { 2 - 4 } & Total & 200 & 100.0 \\
\hline \multirow{3}{*}{$\begin{array}{l}\text { tyculty } \\
\text { type }\end{array}$} & Humane & 108 & 54.0 \\
\cline { 2 - 4 } & Scientific & 92 & 46.0 \\
\cline { 2 - 4 } & Total & 200 & 100.0 \\
\hline
\end{tabular}

\section{Instrument}

A five point Likert scale questionnaire was developed. It consists from (10) statements and seeks investigating the effect of this pandemic on the online purchasing behaviors of consumers in Jordan. The categories used for rating respondents' answerers are: never, sometimes, neutral, often and always. The scores of the latter categories are the following scores: 1, 2, 3, 4 and 5 respectively. Validity

To measure validity, the initial version of the questionnaire was passed to five experts. Those experts were requested to carry out an assessment for the questionnaire. They add that the questionnaire is clear and provide the researcher with accurate, and reliable results. They suggest that the questionnaire is capable of investigating the impacts of this pandemic on the consumer online purchasing behaviors in Jordan. One of the experts suggests that a statement should be re-written to become clearers. Thus, the final version was produced after making such a change.

\section{Reliability}

Calculating the Cronbach alpha coefficient value enabled the researcher to check the scale's reliability. This value is 0.817 . Thus, the results reached through the scale are reliable.

\section{Variables}

Through this research, the researcher targeted several variables. The variables that are targeted by the researcher are listed below:

The independent variables: University, Gender, and faculty type.

The dependent variable: consumer online purchasing behaviors in Jordan. during the COVID 19 pandemic

\section{Statistical Analysis}

The researcher collected the data that is relevant to the study's goals. Then, she employed a program named (SPSS program) in order to have such data 
analyzed. She calculated the relevant percentage, and standard deviations. She calculated frequencies and means The Cronbach alpha coefficient value was identified to present evidence-based information about the reliably of the instrument. In addition, the multivariate analysis of variance was carried out.

The means in this study are classified as follows: 1-2.33: low

\subsection{3-3.67: moderate}

3.67-5: High

\section{Results and Discussion}

Results and discussion related to question one

Q.1: What are the impacts of COVID 19 pandemic on the consumer online purchasing behaviors in Jordan? Table 2 shows the values which are related to the impacts of COVID 19 pandemic on the consumer online purchasing behaviors in Jordan.

Table 2. Values related to the impacts of COVID 19 pandemic on the consumer online purchasing behaviors in Jordan

\begin{tabular}{|c|l|c|c|c|l|}
\hline No & \multicolumn{1}{|c|}{ Statements } & M & S.D & Rank & Degree \\
\hline 7 & $\begin{array}{l}\text { The online purchasing processes allow } \\
\text { me to keep staying at home safely. }\end{array}$ & 3.66 & 1.05 & 1 & Moderate \\
\hline 3 & $\begin{array}{l}\text { The online purchasing processes are } \\
\text { associated with more privacy and } \\
\text { security than the face to face purchasing } \\
\text { processes }\end{array}$ & 3.66 & 0.99 & 2 & Moderate \\
\hline 4 & $\begin{array}{l}\text { I can get everything I want when I carry } \\
\text { out the online purchasing processes }\end{array}$ & 3.66 & 1.05 & 3 & Moderate \\
\hline 5 & $\begin{array}{l}\text { The products purchased are often of } \\
\text { high quality. }\end{array}$ & 3.56 & 1.05 & 4 & Moderate \\
\hline 2 & $\begin{array}{l}\text { The information displayed on online } \\
\text { products is sufficient }\end{array}$ & 3.55 & 1.06 & 5 & Moderate \\
\hline 6 & $\begin{array}{l}\text { I can get all the pieces of information I } \\
\text { want when I seek purchasing products } \\
\text { online }\end{array}$ & 3.54 & 1.07 & 6 & Moderate \\
\hline 9 & $\begin{array}{l}\text { The prices of the products displayed } \\
\text { online are reasonable }\end{array}$ & 3.53 & 1.06 & 7 & Moderate \\
\hline 10 & $\begin{array}{l}\text { There is no exaggeration in the product } \\
\text { prices displayed online }\end{array}$ & 3.52 & 0.86 & 8 & Moderate \\
\hline 1 & $\begin{array}{l}\text { I think the online purchasing processes } \\
\text { allow me to save money }\end{array}$ & 3.51 & 0.71 & 9 & Moderate \\
\hline 8 & $\begin{array}{l}\text { Purchasing products online during the } \\
\text { COVID 19 pandemic allows me to save } \\
\text { time }\end{array}$ & 3.50 & 0.89 & 10 & Moderate \\
\hline & Total & 3.63 & 0.76 & \multicolumn{2}{|c|}{ Moderate } \\
\hline
\end{tabular}

Based on table(2), the researcher found that the COVID 19 pandemic has a moderate impact on the consumer online purchasing behaviors in Jordan. That was concluded the perspective of the students enrolled at Jordanian universities point view. The overall mean is (3.63)which is deemed moderate.

The mean of statement (7) which is 3.66. It's moderate and ranked first. The latter statement states the following: (The online purchasing processes allow me to keep staying at home safely)
The mean of statement (8) which is 3.50. It's moderate and ranked last. The latter statement states the following: (Purchasing products online during the COVID 19 pandemic allows me to save time).

The results related to the first question are consistent with the result reached by Saati [3]. The latter researcher found that the purchasing habits of consumers changed during the COVID 19 pandemic. The results related to the first question are consistent with the result reached by Butu et al 
[10]. The latter researchers found that the COVID 19 pandemic affected the consumer purchasing behavior.

\section{Results and discussion related to question two}

Q.2. Is there any statistically significant difference between the respondents' attitudes which can be attributed to (gender, university, or faculty type)?

Table 3 shows the values that represent the respondents' attitudes in accordance with their (gender, university, or faculty type)

Table3. The values that represent the respondents' attitudes in accordance with their (gender, university, and faculty type)

\begin{tabular}{|l|l|l|l|l|}
\hline \multirow{2}{*}{ Variable } & Category & No & M & S.D \\
\hline \multirow{4}{*}{ Gender } & Male & 119 & 3.44 & 0.971 \\
\cline { 2 - 5 } & Female & 81 & 3.51 & 0.534 \\
\hline \multirow{3}{*}{ University } & University of Jordan & 88 & 3.58 & 0.791 \\
\cline { 2 - 5 } & $\begin{array}{l}\text { Princess Sumaya University For } \\
\text { Technology }\end{array}$ & 65 & 3.61 & 0.911 \\
\cline { 2 - 5 } & Applied Science Private University & 47 & 3.57 & 0.653 \\
\hline \multirow{2}{*}{ Faculty type } & Humane & 108 & 3.61 & 0.771 \\
\cline { 2 - 5 } & Scientific & 92 & 3.65 & 0.894 \\
\hline
\end{tabular}

Based on table3, it appears that there are differences between the respondents' attitudes which can be attributed to (gender, university, and faculty type). To explore whether those differences are statistically Table 4 . The results of the multivariate analysis of variance

\begin{tabular}{llllll}
\hline Source & $\begin{array}{l}\text { Sum of } \\
\text { Squares }\end{array}$ & Df & Mean Square & F & Sig. * \\
\hline Gender & 0.546 & 1 & 0.546 & 0.869 & 0.000 \\
University & 0.076 & 1 & 0.076 & 0.132 & 0.095 \\
faculty type & 9.011 & 1 & 9.011 & 18.311 & 0.130 \\
Error & 81.215 & 197 & 0.600 & & \\
Total & 1869.108 & 200 & & & \\
\hline
\end{tabular}

Based on the fourth table, a statistically significant difference - at the statistical significance level of $\mathrm{a}=0.05-$ is considered existent between the respondents' attitudes that may be attributed to the respondents' gender. This difference is considered the favor of the respondents who are females. In addition, no statistically significant difference - at the statistical significance level of $a=0.05$ - exists between the respondents' attitudes that may be attributed to the faculty type or university of the members of the sample.

The latter results indicate that female have more positive attitudes towards online shopping during the COVID-19 pandemic. This results related to the second question are consistent with the results reached by Pham et al. [6]. The latter researchers significant or not at the statistical significance level of $\mathrm{a}=0.05$, the multivariate analysis of variance was conducted. The results of the latter analysis are presented through table 4 below: found that demographic characteristics (e.g. age, occupation and gender) affect the consumer online shopping behavior.

Having differences in terms of attitudes for the favor of females indicates that females are more influenced by the pandemic in terms of online shopping. That may be attributed to the fact that females in Jordan prefer staying at home more than males during the pandemic. It may be attributed to the fact that females are in need for shopping online during the pandemic more than males, because females are usually responsible for purchasing groceries. The absence of differences between respondents' attitudes which can be attributed to the faculty type or university can be attributed to the fact that universities and faculties don't play a major 
role in changing people's attitudes towards online shopping.

\section{Conclusion}

The researcher concluded the following results:

-The COVID 19 pandemic has a moderate impact on the consumer online purchasing behaviors in Jordan. That was concluded the perspective of the students enrolled at Jordanian universities point view

-There is a statistically significant difference - at the statistical significance level of $\mathrm{a}=0.05$ - between the respondents' attitudes which can be attributed to gender. The latter difference is for the favor of females.

-There isn't statistically significant difference - at the statistical significance level of $a=0.05$ - between the respondents' attitudes which can be attributed to (university, or faculty type).

Through reaching such results, the decision makers in business organizations shall be more capable of making effective decisions for meeting the demands and needs of consumers during the pandemic. In addition, reaching such results shall enable policy makers in public agencies to make effective plans and policies for meeting the demands and needs of consumers during the pandemic. It shall enable policy makers in public agencies to make effective plans and policies for improving the national economy.

\section{Recommendations}

The researcher recommends:

- Taking the recent purchasing trends into consideration when setting marketing plans.

- Jordanian universities should make students aware of the importance of adopting rational methods of procurement in order to reduce the impact of the Corona pandemic on the behavior of the initiator as much as possible.

- The reliance of the local consumer on electronic purchase and payment, and to adapt to the new methods of purchase that became common during the Corona pandemic

- Conducting more studies about the impact of the COVID 19 pandemic on shopping trends and amount of spending.

\section{References}

[1] Bayad, Ali. Impact of COVID-19 on consumer buying behavior toward online shopping in Iraq. Journal of Economic Studies Vol. 18, No.. 42, 2020, p.267-280

[2] Mohammad, Rahman Anisur, Md Aminul Islam, Bushra Humyra Esha, Nahida Sultana, and Sujan, Chakravorty. Consumer Buying Behavior Towards Online Shopping: An Empirical Study on Dhaka City, Bangladesh, Cogent Business and Management, Vol. 5, No. (1), 2018, p. 1-22.

[3] Saati, A. Saudi consumer behavior after the Corona pandemic. Al-Iqtisadiya, Arab International Newspaper:, 2020, https://www.aleqt.com/2020/04/19/article_180 8506.html

[4] Gustav, P., \& Alexandra, V., Changed Buying Behavior in the COVID-19 pandemic -The influence of Price Sensitivity and Perceived Quality. Master Thesis, Kristianstad University SE-291 88 Kristianstad Sweden, 2020

[5] Sharma, A., Jhamb, D., Changing Consumer Behaviours Towards Online Shopping - An Impact Of Covid 19. Academy of Marketing Studies Journal Volume 24, No. 3. 2020

[6] Pham, V., Thi, T., \& Le, T., A study on the COVID-19 awareness affecting the consumer perceived benefits of online shopping in Vietnam.

Cogent Business \& Management Volume 7, No. $\quad 1$. 2020 https://doi.org/10.1080/23311975.2020.184688 2

[7] Vasic, N., Kilibarda, M., \& Kaurin, E., The Influence of Online Shopping Determinants on 
Customer Satisfaction in the Serbian Market. Journal of Theoretical and Applied

Electronic Commerce Research. vol.14 no.2, $2019 . \quad \mathrm{http}: / / \mathrm{dx}$.doi.org/10.4067/S071818762019000200107

[8] Vijai, C., Nivetha, P., A Study On Coronavirus (Covid-19) Impact Of Consumer Buying Behavior With Special Reference To Chennai City. International Conference On Covid-19 Studies At: Ankara. 2020

[9] Debnath, S., Impact of COVID-19 on Consumer Purchase Behaviour in Retail Sector - Study Based in Kolkata Area. (June 24, 2020). 2020 Available at SSRN: https://ssrn.com/abstract $=3634598$ or ht tp://dx.doi.org/10.2139/ssrn.3634598

[10] Butu, A., Ioan S., Lucian, T., Steliana, R., The Impact of COVID-19 Crisis upon the Consumer Buying Behavior of Fresh Vegetables Directly from Local Producers. Case Study: The Quarantined Area of Suceava County, Romania. Int. J. Environ. Res. Public Health Vol. 17, 2020, p. 5485; doi:10.3390/ijerph17155485.

[11] Koch, J., Frommeyer, B., \& Schewe, G. Online Shopping Motives during the COVID-19 Pandemic-Lessons from the Crisis. Sustainability, Vol. 12, 2020, Doi:10.3390/su122410247

[12] Obaidat, Muhammad, Consumer Behavior (A Strategic Introduction), Wael Publishing House, Fourth Edition, Amman - Jordan. 2004

https://www.who.int/ar/emergencies/diseases/novelcoronavirus-2019/advice-for-public/q-acoronaviruses.

[13] UNCTAD, Trade and Development Report 2020, 2020

[14] Digital Research Corporation (DRC), The Impact of the Coronavirus Pandemic on Ecommerce and Consumer Purchasing Behavior in the Kingdom of Saudi Arabia. A report prepared by DRC and submitted in cooperation with the Electronic Commerce and Retail Association. For Digital Research Corporation DRC. 2020

[15] Rajab, Amal, Experts and consumers: The Coronavirus pandemic will affect consumer behavior in the long term. 2020, Oman Newspaper 4/13/2020: https://www.omandaily.om/?p=782407

[16] Hassan, Rahma, Yale University "The Coronavirus Epidemic Between Purchasing Crises, Behavioral Changes, and Corporate Social Responsibility.” Egyptian Observatory, 2020:

https://MARSAD.ECSSTUDIES.COM/24128/

[17] Lawless H.T., and Heymann H., Descriptive analysis. In: Sensory evaluation of food. Food science text series. Springer, Boston, MA, 1999

[18] Chua, C.; and Ruzgar, N. Perceptions of Business Students toward Online Education before and in Transition Period of COVID-19. WSEAS TRANSACTIONS On COMPUTERS, Vol. $\quad 19, \quad 2020, \quad$ DOI: $10.37394 / 23205.2020 .19 .30$

\section{Creative Commons Attribution License 4.0 (Attribution 4.0 International, CC BY 4.0)}

This article is published under the terms of the Creative Commons Attribution License 4.0

https://creativecommons.org/licenses/by/4.0/deed.en_US 